\title{
Migration as a Factor of Regional Ethnic Policy in Siberian Federal District
}

\author{
Leonid V. Savinov* \\ Russian Presidential Academy of National Economy \\ and Public Administration \\ Siberian Institute of Management \\ 6 Nizhegorodskaya Str., Novosibirsk, 630102, Russia
}

Received 19.09.2015, received in revised form 04.12.2015, accepted 27.02.2016

The article deals with the conceptual issues of migration regional policy in the Siberian Federal District. The main challenges of the study are uncovered in the context of federal policy; regional specificity of national policy is indicated. The myths related to migration processes and the reality associated with the economy of modern Russia and its urgent needs for migrant workers are considered.

Keywords: migration policy, Siberian federal district, regions.

DOI: 10.17516/1997-1370-2016-9-4-940-952.

Research area: sociology, politology.

The topic of migration and anthropological flows in the today's world is of particular importance due to the fact that they lead to the meeting and more often, to the clash of cultures, languages, traditions and lifestyles. For Russia, the problem is urgent in view of the weak development of the theoretical and practicalapplied aspects of public relations management, generated by these processes.

Unfortunately, in the framework of foreign academic studies we couldn't find good responses to the challenges of global migration processes. The concept of multiculturalism, defined in the early 70 s of the last century is increasingly criticized today. After the leaders of the major European democracies - D. Cameron, N. Sarkozy, A. Merkel and others, the majority of experts and scholars increasingly question the basic foundations of multiculturalism as a state policy in the sphere of interethnic relations, as well as the civil (political in its nature) and cultural integration in the context of new realities. There is criticism of multiculturalism in one of the programme articles by Vladimir Putin "Russia: the National Question" (Putin, 2012).

That is why the leading ethnopolitologists offer alternative models of dealing with the so-called "national question". From the latest innovations, the model of interculturalism, supported and developed for the Russian conditions by E.A. Pain, calls attention. According to this attitude, "interculturalism suggests the existence of common interests between citizens of different nationalities and religions, united

(C) Siberian Federal University. All rights reserved

* Corresponding author E-mail address: savinov@sapa.nsk.su 
by the common civil liability for their country" (Pain, 2011). Very similar to this view, according to the Russian ethnopolitologist, interculturalism is interpreted in the multi-authored monograph of the Centre for European Policy Studies (CEPS) (Interculturalism, 2011).

In this connection, a scientific discussion about the essence of interculturalism and its differentiation with ideology and social practice of internationalism of the Soviet period seems relevant. Is interculturalism new wine in old wineskins or old wine in new wineskins? Or is it really a new concept in the theory and practice of ethnic policy and solving problems related to migration?

In general, any model of ethnic policy, whether it is monoculturalism, multiculturalism or interculturalism is always a total solution of two issues: the overlapping of political (civil) and cultural (ethnic) borders in the framework of multiethnic society and the content of the political project of a civic nation. Within the framework of this understanding, Soviet internationalism is interculturalism blessed and supported by a specific political content - the communist ideology. The aim of this project was determined by the support and development of cultural diversity within a single new civil (political) community - the Soviet people.

Let us note that the purpose of any ethnic policy is achievement and retention of specific cultural and political identities. And this is the reason why ethnic policy is always instrumental and is constructed, above all, by the political actors, especially by the government and other ethnic entrepreneurs.

Global migration processes significantly intensify the challenges of not only identities of diverse nature and levels, but cultural (ethnic and religious) and political (civil) tolerance as well. The identified problems are significantly intensified in the background and in the context of the meeting and / or collision of the host community and migrants from the different social and cultural worlds. The contact of worldviews and behavioral practices, determined by the results of socialization in the home society and re-socialization in the societies of temporary or permanent residence takes place.

The potential danger of the migration factor is also confirmed by the results of the research project "Ethnicity and Security in Russia in Experts' Estimations", conducted in 2010 by the Institute of Sociology of the RAS in collaboration with the research group ZIRCON (National Security, 2012). The study revealed that among social threats to Russia's national security, tensions in inter-ethnic relations and the increasing number of migrants are closely related threats.

Content analysis of the contemporary debates about migration and its impact upon political, socio-economic, cultural and other processes allows to identify at least three semantic fields of the problem under consideration: migration as a social phenomenon, migration as a social process and migration as a social problem. Such an understanding of migration as a complex structured phenomenon requires a multidisciplinary and systemic approach to its study.

Thus, the study of migration is impossible without systematic identification of its essential and substantial characteristics. In this regard, the ideas of post-national citizenship, cross-cultural exchange and multiculturalism developed in the works of J. Habermas, W. Kymlicka, J. Rosenau et al. (Kymlicka, 2000 et al.) are mainly used in this work in the course of analysis of migration and ethnic policy as interrelated phenomena. Contextual analysis of the characteristics of interdependence of migration and ethnic policy in Russia is based on the results of the scientific achievements by A. Vishnevsky, 
S. Gradirovsky, M. Denisenko, V. Dyatlov, Y. Yefimov, J. Zayonchkovskaya, V. Mukomel, V. Perevedentsev, et. al. (Vishnevsky, 2006; Vishnevsky, 2005; Dyatlov, 2000; Yefimov, 2005; Zayonchkovskaya and Tyuryukanova 2011; Mukomel, 2005; Perevedentsev, 2003).

In the Russian Federation in the context of its complex regionalization and specific characteristics of the territories, connected with the peculiarities of their historical and cultural development, the role of the state as the main political actor in the migration processes management and as the main subject of the ethnic policy is greatly increasing. Under these conditions public authorities should offer reasonable political-administrative and legal responses to migration challenges. At the same time, the role of local government as a level of power at the maximum proximity to a specific person and local communities is significantly increasing. The problem of migration should also be in the focus of close attention of the civil society institutions: political parties and civil society movements, the media, churches, etc.

Solving these problems is the most important task of public and local authorities within the framework of defining and implementation of state and municipal ethnic policy. At that, these problems produce significant risks and threats in relationships between different ethnic and cultural groups, especially native Siberians and new diaspora groups. These problems increase tension in the vertical of power, creating "center regions" problems down the line, that is the problems of real federalism.

In this regard, the management of migration processes is considered within the context of solution of two interrelated tasks:

a) integration of migrants into modern Russian society - inclusion into the sociocultural, economic and political space; б) adoption of migrants by the Russian society, different social groups and by Russians separately, as culturally "other" and "different", but not "alien".

Siberia as a regional community in this case, is an example of a super region that has historically been formed under the strong influence of migration processes ${ }^{1}$. However, according to the authors of the research project "Migration and Diasporas in Socio-Cultural, Economic and Political Space of Siberia, the $19^{\text {th }}$ - early $21^{\text {st }}$ Centuries", despite the similarity of the migration situation in the Russian Empire and the Soviet Union, there are qualitative fundamental differences in the modern Russia. Historically, Siberia was joined to Russia under the guidance of the development of "empty" space. Nowadays, cross-border migrations are a mechanism for the gradual "exclusion" of Siberia from the Russian space. At that, the projects' authors fairly see Siberia as not only as a territory, bus as a specific type of social organization, as a specific type of culture and tradition, that has historically been emerging and developing "beyond the Urals" (Migration and Diasporas ..., 2010).

Under these conditions, within the frames of the system analysis, Siberia can be viewed as a black box with the high degree of uncertainty, which, at the entrance to the Siberian society has large incoming migration flow, and at the exit multiple problems of socio-cultural, economic and political nature.

Analysis of the research achievements of the Russian scientists allows to identify four main areas of migrants' integration into contemporary Russian society: economic, political, sociocultural and within the frames of the social subsystem of kinship (according to T. Parsons).

We have attempted to identify the possibilities and the level of integration in these areas in the course of in-depth interviews with migrants and 
Table 1. The level of integration into the russian society, rating

\begin{tabular}{|l|l|c|c|c|}
\hline № & \multicolumn{1}{|c|}{ Social sphere (subsystem) } & The 1990s & The 2000s & The 2010s* \\
\hline 1 & Economics & 1 & $1-2$ & $2-3$ \\
\hline 2 & Politics & $3-4$ & $2-3$ & $1-2$ \\
\hline 3 & Culture & 2 & $3-4$ & $3-4$ \\
\hline 4 & Kinship & 4 & 3 & 3 \\
\hline
\end{tabular}

* predicted values, mostly.

experts held in 2008 and 2011. The ranked results are presented in Table 1.

As we can see over the years the situation has changed and requires further analysis and interpretation. In the $90 \mathrm{~s}$ of the last century motivations and aspirations towards integration were mainly in the sphere of economics and culture. Migrants of the $90 \mathrm{~s}$, along with the desire to find a job and income, still remembered a single linguistic and cultural space and tried to preserve it. At the same time, migrants of that period virtually did not set the goal to create a family (including mixed marriage), or bring the family to Russia.

In the 2000s the priorities have changed, and we can see a shift of integration moods. Economic motivation still prevails, however, striving to get permanent residence with bringing family and become naturalized become important for migrants in this period. Decline in the interest to the cultural involvement into the host society was observable at the same period. At the turn of 2000s - 2010s only those, who had completely forgotten the common cultural past, or had never known it, went to Russia. And in the 2000s there was a significant increase in diasporas' activity in national and cultural autonomies and national organizations establishment.

Beginning of the 2010s was marked by the increased interest of migrants to the political involvement, mainly to naturalization and participation in electoral processes. Even in the second half of the 2000s we witnessed the increasing demand of emigrant communities' leaders of Siberian cities to their inclusion into various advisory and consultative bodies of the state and local government. Elections to the State Duma in 2011 indicated that ethnic factor became one of the priorities in the election campaign. The elite of ethnic diasporas tried to take advantage of it, sometimes making political demands for participation in local government.

The results of our opinion polls and expert opinions indicate of the fact that in SFD immigrants' motivation and requirements (most likely, as well as within the Russian Federation) have considerably changed. Labour (economic) motivation is being gradually replaced by social motivation in its broad sense and, as a consequence, by the political and cultural requirements. And if in 90s of the last century, migration was mostly labour and temporary, in the first decade of the twentieth century it tended to acquiring Russian citizenship. And today this tendency is strengthening more and more.

From the standpoint of economics and classical political economy this phenomenon, in our opinion, can be well-explained within the theory of "dual" economy, as well as "dual" and "segmented" labor markets (Wiener and Tavrovsky, 2009).

In the conception of dual economy the core is characterized by "the high capital intensity, vertical integration of production, technological innovations, national or international scale, diversification, high profits, monopolistic power 
in the commodity markets, organization of the internal labor market, etc. These characteristics are less pronounced on the periphery" (Sakamoto, 1988 , p. 89). Moreover, the core mainly consists of "good" jobs, and the periphery - of all the rest. At that, the concept of "dualism" refers to three interconnected, but not identical positions:

1) dual economy, i.e. the separation of the economy into the core and peripheral sectors on the basis of market power;

2) dual labour market, i.e. classification of labour markets (for recruitment and promotion) as providing or not providing staff with job security and internal promotion ladders;

3) dual labour, i.e. the division of labour on a more or less privileged, not competing with each other categories of staff (for example, ethnic). People belonging to the "primary" (privileged) categories of the labor power usually get the job on the core of economy. Labour markets in the economic core tend to be internal ("primary"). For example, we can find adult white men at the domestic labour markets in the economic core where the salary is high; environment is comfortable and job security is high (Simpson, 1989, p.567).

In the case of modern Russia, we have the economic core and the periphery in two representations: internal and external. Inside Russia, there is a center - the capital, and the periphery is its suburbs, mainly Siberia and the Far East. In the external representation the Russian Federation itself acts as the core in relation to the majority of the former Soviet republics that are sovereign states now.

In addition to the core and the periphery, in economic literature it is also possible to find separations into specific segments of the economy of enclave markets, including ethnic. Nowadays such labour markets are widely discussed in the sociology of ethnic relations. These markets are described as an addition to the monopolistic companies (primary labour market) and small businesses (secondary labour market). But, in contrast to the secondary market, where investments into human capital is not coved, in the enclave economy investments of migrant workers into human capital are covered in the same way as it happens in the primary market. In the core of economy monopolistic firms are vertically and horizontally integrated. A lot of small "atomized" businesses function on the periphery. Enclave economy consists of a cluster of small businesses that are horizontally and vertically integrated ${ }^{2}$.

Due to the considerable labor migrations to the big Siberian cities, certain sectors of economy where the proportion of migrants becomes dominant can be identified: construction, trade, housing and communal services, transportation and the service sector.

Another important aspect of migrant incorporation is the problem of their integration into the new political realities (the state, citizenship, political participation, etc.), and the political culture of the host society. In this connection the work of the Ural political scientist A. Chesnokov (Chesnokov, 2009a; Chesnokov 2009b) should be noted.

The author rightly points out that one of the main instruments of migrant integration into the host society is the practice of granting political rights in the form of participation in elections, as a rule, at the local level. Along with that, political rights of immigrants are not limited by electoral rights. Another important tool for integration is to involve immigrants into public life. And this involvement, as a rule, happens in two forms.

The first form is creation of a special advisory structures affiliated to the executive and legislative bodies (at the local or regional levels) that include representatives of institutionalized immigrant communities - people from one country or members of certain ethnic groups, residing in the territory of the corresponding territorial units. As 
a rule, these communities unite both non-citizen immigrants and immigrants who have already become citizens of the host state. Advisory structures, affiliated to the official authorities have advisory functions and have the right to participate in the discussion of the authorities decisions in the part directly related to immigrant communities.

The second form of migrant involvement into public life is to encourage their participation (within the frames of acting laws) in the activities of the already existing in the host country various social and political organizations (political parties, trade unions, mass media and communications, charities, human rights, religious, etc.). As civil society institution, such organizations on the one hand, contribute to the complex integration of immigrants into the social and political structure of the host country and, on the other hand, allow immigrants to protect and lobby for their interests at the expense of the institutionalization of immigrant groups and the use of acceptable in the country channels and tools for the dialogue with the authorities more effectively.

It is through non-governmental organizations, as A. Chesnokov reasonably notes, the states that accept immigrants can successfully implement various integration projects: from spreading general information about various aspects of social, cultural and economic life in the host country, contribute to employment and getting education to informing foreigners of their rights and obligations and, in particular, promoting electoral and civic engagement among non-citizens and naturalized citizens (Chesnokov, 2009b).

In the Message of the President of the Russian Federation Dmitry Medvedev to the Federal Assembly in November 2008, the concepts of "the Russian nation" and "the unity of the multicultural nation" received strong political support (Message ...). However, neither the
Russian nation, nor its unity is impossible without the state ethnic policy adequate to historical time and social space.

In contrast to this, in one of the programme articles of a candidate for the presidency Vladimir Putin "Russia: The National Question" nothing was said about the Russian nation or Russians as fellow citizens (Putin 2012). From the author's point of view, this indicates of the fact that the political elite of the modern Russia doesn't have consolidated and unified position on the important political issue: the essence and the content of the state ethnic policy. In fact, we are talking about the ways and mechanisms of solving the socalled national question, including in relation to migration as a major factor of complicating ethno-social processes.

According to Heleniak's study (2002), there are four major problems in the field of migration in Russia: (a) "brain drain", (b) the influx of migrants from the CIS countries, (c) depopulation of Siberia and ( $\mathrm{g}$ ) turning Russia into the "migration magnet" for immigrants from the countries with low income level, especially from China and South Asia (Heleniak, 2003). The scope of the aforementioned problem isn't big compared to others, but its importance will increase as long as Russia continues its economic growth and hundreds of millions of people from mainland China will have sufficient income to migrate.

Recent polls indicate of strengthening antimigrant moods (Andrienko and Guriev, 2006). In quantitative terms, the degree of intolerance among Russians is not higher than that among Americans, Europeans and Australians. The results of public opinion polls, which were carried out in seven "immigration" and "nonimmigration" countries (the USA, Australia, Canada, the UK, France, Germany and Japan), indicate that the majority of people in these countries treat immigrants with fear, hostility or, 
in the best case, with indifference (Simon, 2004). The analysis of data from the European Social Survey 2003 on attitudes towards minorities and migrants in different EU countries demonstrated that in societies there is no unity on this question: younger citizens with better education and higher income level are less opposed by cultural and religious diversity (EUMC, 2005). In addition, the level of GDP per capita makes important influence: in the countries with higher income level ethnic isolationism is less pronounced.

Migration regulation programmes (also known as "amnesties for immigrants") are used in most of the host countries: since 1967 in America (Canada) and since 1973 in Europe (France). Within the frame of these programmes permanent or temporary legal status is granted to a significant part of the existing at the moment of illegal immigrants. Such programmes are an important tool for immigration policies in the countries of Southern Europe, where they are implemented almost continuously: with the help of 7 programmes 850000 workers were legalized in Italy, in Spain by 2006 programmes were implemented, within which 615000 permits were granted; there were 700000 applicants in the programme of 2005. In Portugal 180000 immigrants were legalized by 4 programmes, in Greece there were 570000 applicants in 2 programmes (Papandopolu, 2005). In the USA, on the basis of Immigration Reform and Control Act of 1986 (the largest immigration amnesty) 2.7 million residence permits were granted. The current administration of the US is also considering the possibility of a new immigration amnesty, which scope can be even more significant, covering 10 million illegal immigrants (Borjas, 2004).

Migration policy in Russia followed the experience of the developed countries, where there are the same problems of aging population and the need to attract immigrants to enlarge workforce. The policy in these countries is often excessively repressive as it is based on the relationships of a median worker who is not highly qualified and therefore, is afraid of competition in the labor market. Negative attitude towards migrants is also generated by the fear that cultural self-identification will be "blurred". In Russia, both of these points are of less importance. Firstly, approaches and strategies in Russia are formed for the benefits of the highly skilled elite. Secondly, the vast majority of immigrants are ethnic Russian or Russian-speaking residents of the former Soviet republics. There are some other differences between Russia and OECD countries. In Russia, in particular, the potential of the law enforcement agencies is much less. That is why administrative barriers on migration's way are transformed into a source of rents and bribes for officials, which leads to the emergence of numerous illegal immigrations. According to the current estimations, in percentage terms, the share of illegal immigrants in the labor force is not less than that which is observed in the USA or the EU. In addition, law enforcement agencies in general are less effective, and that is why the social cost of the large number of illegal immigrants in Russia is much higher than in OECD countries. This situation supposes that Russian leaders will soon have to carry out the same immigration amnesty, as their Western colleagues do (Andrienko and Guriev, 2006).

Against the background of the negative natural population growth migrants are an important part of the labor potential of Siberia and Russia as a whole. Siberia that occupies boundary position with the countries of Central Asia, takes one of the first places in the country in the degree of foreign labor migration activity. By now, the practice of penetration and settlement of migrants, as well as the practice of economic integration of migration agents has formed. In this connection, entirely new problems have arisen in 
Siberia, including those of ethnic and cultural security. The question is how to organize the coexistence of different ethnic groups in the same territory, in the way that cultural exchanges could enrich different ethnic groups, but do not produce painful social phenomena, and that the region that receive immigrants could use the international labour to its maximum to build its economic and demographic potential (International Migrants ... 2006).

The fate of the migration policy concept was not easy. According to Konstantin Romodanovsky, it started in 2005 with the efforts of 47 structures, and then it had long been discussed at different levels. However, in 2009, they had to start work from the scratch (Migration of Contention ...). The concept was discussed twice at the meetings of the governmental commission on migration policy, and experts agree that the current project is the most successful: it fully covers the goals, objectives and immigration mechanisms, reduces the risks of the migrant integration into the Russian society. And only in June 2012 the Concept of the State Migration Policy of the Russian Federation was approved by the President of the Russian Federation V. Putin.

The population of Russia is decreasing and aging, and year by year it is more and more difficult to find the resources for innovative development. In addition, internal migration takes place: people leave their habitual residence and travel to the capital in search for happiness and higher wages. As a result, Siberia and Far East are becoming underpopulated (for the first 5 months of 2011, the Far East lost 6000 people), and strengthening of these regions is becoming one of the migration policy objectives. When discussing the concept, there were proposals to stimulate migration to Siberia from the places with excessive labor resources, and they include not only Moscow and St. Petersburg, but also a number of Caucasian regions.
Attracting migrants from abroad is another way to increase labour resources of the country. And it is not only attracting, it is evident that there is a large number of migrant workers in the country, but the civilized and described in the law procedure that could help active citizens from other countries to have every right to live and work in Russia and have certain rights and responsibilities.

A lot of attention is paid to educational migration, and it is quite reasonable: a person who graduated from the University in Russia is, a priori, well prepared to work in the Russian Federation, knows the laws and traditions and will not be restrained by the family and ethnic groups.

It is important for "our" migrants to know the Russian language well, as well as historical background of the country and culture of the people. In this regard, the discussion raised the issue of the introduction of the scores system to evaluate potential migrants. Such systems already operate in Canada, Australia and some other countries and help to assess a person's possibility to integrate into society with the help of entrance tests. On the one hand, such system has certain prospects; it is deprived of corruption component and may well prove its efficiency. On the other hand, we know all the difficulties connected with the widely discussed Unified State Exam, and it is evident that for migrants the exam is unlikely to be much easier to pass.

It essential to highlight that although the country needs migrants, there will not be any particular facilitation to the naturalization procedures in Russia in the nearest future and it will not be easier to obtain Russian citizenship to migrants than it is now. No special indulgences are also expected in regard to the migrants' families. Therefore, the current concept is rather an attempt to normalize the existing relationship, give them a legal basis and to attract to Russia 
the best representatives of the neighboring states, carriers of cultural and intellectual property, and not to arrange a massive influx of migrants.

Nobody doubts in the fact that the global economic crisis in Russia is not over yet. One of the indicators is activation of the foreign migrant flows to the territory of Russia, including the regions of the Siberian Federal District.

In 20111.7 million foreigners crossed the Russian border within the territory of the SFD, at that more than 0.95 million people entered the territory of Russia, which is $18 \%$ more than in 2010, and 0.77 million people left the territory. The third of foreigners use the territory of the District as a transit area and go further to the regions of central Russia, and the rest associate their future plans for work, study and travel with Siberia.

This year 566 thousand foreign citizens have arrived to the territory of the districts, which is $14 \%$ more than in 2010. Traditionally, the most part of the foreigners is represented by the citizens of the CIS countries - more than $70 \%$ of the arrived. Other countries are mainly represented by citizens of China. For work and residence foreigners prefer Irkutsk Region, Novosibirsk Oblast and the Krasnoyarsk Territory.

Today, on the basis of the temporary residence permit and residence permit more than 58 thousand foreign citizens, which are dominated by people from the neighboring countries (Uzbekistan, Tajikistan), reside in the regions of Siberia, 16.6 thousand foreigners became Russian citizens last year.

The majority of foreigners come to Siberia in search of work. During 2011, 82 thousand foreign citizens from 60 countries worked in the territory of the Siberian Federal District. Blue collars form the basis of the foreign labor migration flows: most of the foreigners got permission to work as general labourers and freight handlers, foreign workers tend to apply for the jobs that are not popular among the local population, regardless of education, and are ready to do unskilled work that, first and foremost, requires manual work. More than $40 \%$ of labour migrants are employed in the construction sector, $13 \%$ in agriculture and forestry, $12 \%$ are employed in the manufacturing sector.

The most typical image of a migrant worker in Siberia is an immigrant from Uzbekistan (Tajikistan and Kyrgyzstan), aged from 18 to 49, working in the construction industry.

Despite the fact that unskilled blue collar jobs dominate among foreign labour migrants, there is a tendency in increase in the number of qualified specialists: in 2011, 1528 qualified foreign specialists carried out labor activity in the territory of the District.

For the period of seven months in 2011, 72 thousand migrant workers worked on the basis of patent for individuals (construction of country houses and detached houses, flats redecoration, cleaning, babysitting, etc.).

To provide priority employment of Russian citizens, Migration Service of Russia has significantly tightened regulations for the organizations that employ foreigners. Minimize the number of employers hiring foreigners to work in the timber industry, agriculture, transportation and trade that are popular among Russian citizens. Organizations that provide mediation services, as well as fly-by-night companies that are not engaged in any kind of activity are excluded from the list of companies that attract foreign workers. It resulted in a significant reduction in the number of migrants in the Russian labour market: as at the end of July 2011, according to the data from the employment services, 638902 vacancies and 309386 unemployed persons were registered in the District. Jobs that attract foreign workers are not in demand among the local population.

The increased intensity of migration flows has attracted close attention of the FMS 
of Russia to conformity with the migration legislation of the Russian Federation both by the foreigners and the Russian citizens. During 2011, the Migration Service of Siberia detected more than 268 thousand offenses in the field of migration, more than 41 thousand foreigners, who violated the established order of residence and employment, were held administratively liable. 118 channels of illegal migration were terminated. The budget was replenished by 297 thousand Rub., received as fines for the violations.

Tough measures are taken to the violators of migration legislation: 7 thousand foreigners were denied entry to the territory of Russia; 3 thousand foreign citizens were deported from the Russian Federation.

In general, the territory of Siberia has become a comfortable "temporary home" for the law-abiding foreigners. Typical for the multinational population of Siberia neighborly attitude towards representatives of other states, as well as effective operation of the Migration Service offices in identifying violators of the Russian legislation provide absence of international conflicts and other factors that destabilize social situation in the regions of Siberia (Migration Situation ... ).

According to the results of our research, we have come to the following conclusions:

1. In the opinions of the large number of population, migration in the Siberian Federal District is becoming a social problems and a threat to the individual security, society and the state. It is not connected with the objective increase in the number of migrants, but with the subjective perceptions of their number, based on the visualization of migrants in the public areas: trade, food service, transportation, housing, service sector, etc.

2. As for its inner content and driving forces, migration moves from the economic sphere to the social and political sphere. Labour migration is increasingly being replaced and / or initiated by social factors: a higher level and quality of life, access to quality health care services and education.

1. The high level of personal security is a significant factor for migrants in determining Siberia as a region and territory of migratory preferences. The level of host country hostility is lower in comparison with Central and Southern Russia.

2. Immigrants from the neighboring countries establish significant in their consolidation and opportunities diasporas in the large cities of the SFD that aim at ethno-cultural autonomy with the use of political demands and threats. This diasporas are largely structured by the network principle and managed by informal social leaders, many of whom are religious and / or criminal authorities.

3. Official national-cultural autonomies and ethno-national organizations of migrants from the neighboring countries are characterized by the weak involvement of the "new" migrants. They mostly have presentational characteristics. Many leaders use statuses of the heads of these structures as a tool to achieve their personal small group (clan, family, etc.) political and economic or other purposes.

6. The threat of the significant anthropological flow from abroad, especially from China is a "subjective reality" for the population of Siberia (according the Thomas theorem) and the myth as an "objective reality". The number of migrants from China decreased with the increase of China's economy. Siberia is not a priority immigration area and territory for the Chinese. At home, in more comfortable socio-cultural conditions, potential migrants nowadays are able to get the expected benefits.

7. Immigrants from the other countries are very passive in establishing national 
cultural autonomies and national ethnic integrated into the Russian civilization, social organizations. At that, they are poorly and political space.

\footnotetext{
The problematics of migration and ethnic policy in Siberian Federal District (SFD) is one of the directions of our research project, which was launched in 2001 and continues up to date. In the course of study sociological sampling, using quantitative and qualitative methods was conducted in seven subjects of the SFO: the Altai and the Krasnoyarsk Territory, Novosibirsk and Irkutsk regions, in the Altai Republic, the republics of Buryatia, Tyva and Khakassia, as well as the UstOrda Buryat Autonomous Okrug. Polls with the use of representative quota sample (statistical error of $+/-3.7 \%$ ), expert interviews and focus groups were conducted in 2001, 2004, 2008 and 2011.

2 See more details on migrants in the spheres of small and medium-sized business in Russia in Research Digest "Migration as a Factor for Small and Medium-Sized Business and Russian Economy Development", Available at: http://opora.ru/ analysis/research/5325. (Accessed 21.01.2012).
}

\section{References}

Heleniak, T. (2002). Migration Dilemmas Haunt Post-Soviet Russia, Migration Policy Institute.

Hill, F., Gaddy, C. (2003). The Siberian Curse: How Communist Planners Left Russia Out in the Cold. Washington, D.C., Brookings Institution Press.

Interculturalism. Europe and Its Muslims in Search of Sound Societal Models (2011). Ed. by Michael Emerson. Brussels, Center for European Policy Studies.

Kymlicka, W., Norman W. (eds.) (2000). Citizenship in Diverse Societies. Oxford.

Sakamoto, A. (1988). Labor Market Structure, Human Capital, and Earnings Inequality in Metropolitan Areas, In Social Forces, 67 (1), 89.

Simpson, I.H. (1989). The Sociology of Work: Where Have the Workers Gone?, In Social Forces, 67 (3),567.

Andrienko, Yu., Guriev, S.(2006). Analiz migratsii v Rossii [Analysis of Migration in Russia], In Centre for Economic and Financial Research at New Economic School. Analytical Studies and Reports, 23 (April), 27.

Andrienko, Yu., Guriev, S. (2006). Analiz migratsii v Rossii [Analysis of Migration in Russia], In Centre for Economic and Financial Research at New Economic School. Analytical Studies and Reports, 23 (April), 38.

Wiener, B.E., Tavrovsky, A.V. (2009). Migranty na rynkakh truda v Sankt-Peterburge [Migrants in St. Petersburg Labour Markets], In Journal of Sociology and Social Anthropology, 12 (4), 97-121.

Vishnevsky, A.G. (2006). Demographicheskaia modernizatsiia Rossii, 1900-2000 [Demographic Modernization of Russia, 1900-2000]. Moscow.

Vishnevsky, A.G. (2005). Izbrannye demographicheskie trudy [Selected Works on Demography], in 2 volumes. Moscow.

Research Digest "Migration as a Factor for Small and Medium-Sized Business and Russian Economy Development", Available at: http://opora.ru/analysis/research/5325. (Accessed 21.01.2012).

Dyatlov, V.I. (2000). Sovremennye torgovye men'shinstva: factor stabil'nosti ili konflikta? (Kitaitsy i kavkazstsy v Irkutske) [Contemporary Trade Minorities: a Factor of Stability or Conflict? (Chinese and Caucasians in Irkutsk)]. Moscow.

Yefimov, Y.G. (2005). Politicheskaya migratsiologiia: migratsionnye protsessy v kontekste politologicheskikh problem [Political Migrationology: Migration Processes in the Context of Politological Problems]. Moscow. 
Zayonchkovskaya, J.A., Tyuryukanova, E.V. (2011). Migratsiia i demographicheskii krizis v Rossii [Migration and Demographic Crisis in Russia]. Moscow.

Inostrannye migranty v Sibiri [International Migrants in Siberia] (2006), in Science in Siberia, 49 (2584), 21 December, 6.

Migratsii $i$ diaspory $v$ sotsiokul'turnom, politicheskom $i$ ekonomicheskom prostranstve Sibiri. Rubezhi XIX-XX and XX-XXI vekov [Migration and Diasporas in Socio-Cultural, Economic and Political Space of Siberia. The 19th - Early $21^{\text {st }}$ Centuries] (2010). Science editor V.I. Dyatlov, Irkutsk, Ottisk, $640 \mathrm{p}$.

Migratsionnaya situatsiia v Sibirskom Federal'nom Okruge [Migration Situation in Siberian Federal District] Available at: http://www.fms-nso.ru/ufms/SFO/

Migratsiia razdora [Migration of Contention]. Available at: http://top.oprf.ru/main/3813.html

Mukomel, V.I. (2005). Migratsionnaya politika Rossii. Postsovietskie konteksty [Migration Policy in Russia. Post-Soviet Contexts]. Moscow.

Natsional'nost' i bezopastnost' Rossii v otsenkakh ekspertov. Analiticheskii otchet po rezul 'tatam ekspertnogo oprosa [Ethnicity and Security in Russia in Experts' Estimations. Analytical Report on Experts Poll Results]. Available at: http://www.vestnik.isras.ru/files/File/Gorshkov_analit.otchot.pdf. (Accessed 25. 01. 2012).

Pain, E.A. (2011). Trudnyi put' ot mul'ticulturalizma k interkulturalizmy [Difficult Way From Multiculturalism to Interculturalism], In Bulletin of Kennan Institute in Russia, 20, (in print).

Perevedentsev, V.I. (2003). Migratsiia naselenia i demographicheskoe budushchee Rossii: (nauchno-analiticheskii doklad) [Migration of Population and Demographic Future of Russia (Scientific and Analytical Report)]. Moscow.

Politika immigratsii i naturalizatsii v Rossii: sostoianie del i napravleniia razvitiia. Analiticheskii doklad [Immigration and Naturalization Policy in Russia: Current Situation and Course of Development. Analytical Report] (2005). Edited by S.N. Gradirovsky. Moscow.

Poslanie Federal'nomy Sobraniiu Rossiiskoi Federatsii [Message to the Federal Assembly of the Russian Federation], In the President of the Russian Federation. Available at: http://www.kremlin.ru/ appears/2008/11/05/1349_type63372type63374type63381type82634_208749.shtml

Putin, V. (2012). Natsional'nyi vopros [The National Question], In Nezavisimaya Gazeta, 23 January.

Putin, V.V. (2012). Rossiia: natsional'nyi vopros [Russia: the National Question]. Available at: http://putin2012.ru/\#article-2 (Accessed 26.01.2012).

Chesnokov, A.S. (2009). Politika reguliroviniia migratsionnykh protsessov vo vtoroi polovine $X X$ - nachale XXI vekov. Monographiia [Migration Processes Regulation Policy in the Late $20^{\text {th }}-$ Early $21^{\text {st }}$ Centuries. Monograph]. Ekaterinburg, Ural State University Publishing House, 166.

Chesnokov, A.S. (2009). Teoretiko-metodologicheskie podkhody $\mathrm{k}$ analizy vliianiia migratsii na politicheskie protsessy [Theoretical and Methodological Approaches to the Analysis of Migration Effect on Political Processes], In Society and Power, 1, 50-54.

Chesnokov, A.S. (2009). Uchastie immigrantov-negrazhdan $\mathrm{v}$ politicheskikh protcessakh $\mathrm{v}$ prinimauishchikh stranakh [Participation of Non-Citizen Immigrants in Political Processes of the Host Countries], In Society and Power, 4, 49-54.

$$
-951-
$$




\section{Миграция как фактор региональной этнополитики \\ в Сибирском федеральном округе}

Л.В. Савинов

Российская академия народного хозяйства и государственной службы при Президенте Российской Федерации Сибирский институт управления Россия, 630102, Новосибирск, ул.Нижегородская, 6

В статье рассматриваются концептуальные вопросы миграционной региональной политики в Сибирском федеральном округе. Основные проблемы исследования раскрываются в контексте федеральной политики, указывается региональная специфика национальной политики. Рассматриваются мифы, связанные с миграчионными процессами, и реальность, связанная с экономикой современной России и ее насущными потребностями в трудовых мигрантах.

Ключевые слова: миграционная политика, Сибирский федеральный округ, регионы.

Научная специальность: 22.00.00 - сочиологические науки, 23.00.00- политология. 